Studies of the Industrial Geography Commission of the Polish Geographical Society

29(2) $\cdot 2015$

Marlena Dyszy

Uniwersytet Śląski, Katowice, Polska • University of Silesia, Katowice, Poland

\title{
Budownictwo jako czynnik dynamizujący rozwój strefy podmiejskiej na przykładzie wybranych gmin w otoczeniu aglomeracii górnośląskiej
}

\section{Construction as a Factor in the Dynamic Development of the Suburban Area on the Example of Selected Municipalities in the Surrounding Silesian Agglomeration}

Streszczenie: Gminy wiejskie wchodzące w skład strefy podmiejskiej większego zespołu miejskiego odgrywają w dzisiejszych czasach ważną rolę w systemie osadniczym. Są to tereny różnorodne, na których zachodzi wiele interesujących zjawisk społecznych i gospodarczych. Wraz z ciągłym rozwojem obszarów miejskich strefy podmiejskie zyskują na znaczeniu, gdyż coraz częściej przenosi się do nich życie społeczne i gospodarcze. Przedmiotem pracy jest charakterystyka funkcjonowania działalności budowlanej rozwijającej się w obszarze podmiejskim większego zespołu miejskiego. Celem szczegółowym pracy jest przedstawienie rozwoju nowego budownictwa na terenie dwóch gmin województwa śląskiego, w Bobrownikach oraz Ożarowicach, położonych w centralnej części województwa śląskiego i sąsiadujących z miastami wchodzącymi w skład aglomeracji górnośląskiej. Aby pozyskać odpowiednie dane, wykorzystano metodę inwentaryzacyjną, za pomocą której zostały spisane wszystkie nowe budynki mieszkaniowe powstałe na terenie analizowanych gmin. Istotnym czynnikiem warunkującym rozwój budownictwa są ceny ziemi. Zagadnienie to omówiono na przykładzie cen gruntów budowlanych, z uwzględnieniem działek budowlanych oraz - w kilku przypadkach - działek budowlano-usługowych, bez zabudowy. W szerszym zakresie omówiono zagadnienia z zakresu budownictwa mieszkaniowego. Przede wszystkim ukazano dynamikę rozwoju nowego budownictwa mieszkaniowego. Przeprowadzono podział nowej zabudowy na dwie grupy: pojedyncze budynki mieszkaniowe oraz osiedla mieszkaniowe. Podjęto próbę przedstawienia budownictwa jako jednego z ważniejszych czynników wpływających na rozwój obszaru podmiejskiego. Na całym terenie, któremu poświęcona jest niniejsza praca, odbywa się wzrost natężenia w ruchu budowlanym. Generuje go napływ ludności, głównie miejskiej. Z tego powodu obszar podmiejski ulega ciągłym zmianom, uzyskując stopniowo cechy upodobniające go do miasta.

Abstract: Rural municipalities included in the suburban area of larger conurbations presently play an important role in the settlement system. These are diverse areas where many interesting social and economic effects take place. Along with the continuous development of urban areas, suburban areas are becoming increasingly important due to the transfer of social and economic life to those areas, 
which is an integral part of the surrounding urban areas. The subject of the work is the construction developing suburban area of a larger conurbation. The aim of this paper is to present the development of new construction works in two municipalities of Silesia: Bobrowniki and Ożarowice located in the central part of Silesia and adjoining towns belonging to the Silesian agglomeration. Source material comprises fieldwork during which an inventory was made of all new residential buildings constructed in the analysed municipalities. An important factor in the development of the construction industry is the price of the land. This issue was raised on the example of prices of building land, including building plots and, in a few cases, empty construction and building plots. Issues within the scope of housing have been discussed in a wider scope. First of all, the dynamics of the development of new housing have been presented. New residential developments have been divided into two groups: single residential buildings and housing estates. The paper aims to present construction as one of the most important factors affecting the development of the suburban area. On the whole area, which is dedicated to this work is done in the increase in the intensity of traffic building. The surge of people, mainly urban, generates an increase in construction traffic. Because of this, the suburban area is constantly changing, gradually gaining features similar to those of a city.

Słowa kluczowe: aglomeracja górnośląska; budownictwo; gminy wiejskie; strefa podmiejska Keywords: Silesian agglomeration; construction; rural municipalities; suburban area

Otrzymano: 19 grudnia 2014

Received: 19 December 2014

Zaakceptowano: 21 czerwca 2015

Accepted: 21 June 2015

\section{Sugerowana cytacja / Suggested citation:}

Dyszy, M. (2015). Budownictwo jako czynnik dynamizujący rozwój strefy podmiejskiej na przykładzie wybranych gmin w otoczeniu aglomeracji górnośląskiej. Prace Komisji Geografii Przemysłu Polskiego Towarzystwa Geograficznego, 29(2), 113-122.

\section{WsTĘP}

Przedmiotem artykułu jest rozwój budownictwa na obszarze podmiejskim, w otoczeniu większego zespołu miejskiego, jakim jest aglomeracja górnośląska. Budownictwo jest jednym spośród wielu elementów, dzięki któremu można ocenić, w jakim tempie i kierunku następuje rozwój strefy podmiejskiej. Strefa podmiejska to obszar, który leży na pograniczu miasta i wsi. Z uwagi na różne funkcje, które miejsce pełni, strefa ta odgrywa coraz większą rolę w zagospodarowaniu przestrzennym. Pod względem społeczno-ekonomicznym jest to obszar mocno zróżnicowany, o wyraźnym braku granicy miejskości i wiejskości.

Celem artykułu jest przedstawienie rozwoju budownictwa na obszarze gmin Bobrowniki i Ożarowice, które położone są w centralnej części województwa śląskiego i sąsiadują z miastami wchodzącymi w skład aglomeracji górnośląskiej. Niniejsze opracowanie ma również na celu ukazanie, jak ważną rolę w systemie osadniczym odgrywa strefa podmiejska, która ma złożony, zróżnicowany i dynamiczny charakter. Materiał źródłowy stanowiły wyniki badań terenowych przeprowadzonych w 2013 roku. Inwentaryzacją zostały objęte nowo powstałe budynki. Podczas inwentaryzacji wzięto pod uwagę kryterium lokalizacji, typ zabudowy, pełnione funkcje oraz wielkość budynku. W czasie prowadzonych badań zabudowa została podzielona na dwie grupy. Pierwsza grupa obejmowała zinwentaryzowane nowe 
budynki, natomiast druga grupa - nowe budynki jednorodzinne tworzące osiedla mieszkaniowe. Cały obszar badań został podzielony na mniejsze części. Badania w terenie były prowadzone we wszystkich sołectwach analizowanych gmin.

\section{STREFA PODMIEJSKA}

Heterogeniczność strefy podmiejskiej powoduje, że w literaturze występuje duża liczba prób jej definiowania. Można wyróżnić dwa podstawowe podejścia - funkcjonalne i strukturalne. Podejście funkcjonalne obejmuje powiązania ekonomiczne i społeczne z miastem. Podejście strukturalne to kształtowanie się cech społeczno-gospodarczych (Bański, 2008). Definicje konstruowane w oparciu o aspekt strukturalny nawiązują do form osadniczych, jak również do poszczególnych zjawisk związanych z zaawansowaniem procesów urbanistycznych. W aspekcie funkcjonalnym określa się funkcje pełnione na rzecz miasta przez tereny położone wokół niego oraz te aspekty, które powodują nasilenie powiązań wynikających z pełnienia tych funkcji (Jurek, 1991).

Konsekwencją różnorodnych definicji strefy podmiejskiej jest mnogość metody jej delimitacji. W zakresie kryterium funkcjonalnego do wyznaczenia strefy podmiejskiej wykorzystuje się: zasięg i natężenie dojazdów do pracy, funkcje gospodarcze pełnione przez obszar, kategorie zagospodarowania ziemi i ich zmienność itp. W kryterium strukturalnym analizuje się ogół cech diagnostycznych (struktura użytkowania ziemi, gęstość zabudowy, gęstość zaludnienia itp.), dla których przyjmuje się pewne wartości progowe wyznaczające strefę podmiejską (Bański, 2008).

R. Pryor (1968) uważa, że strefę podmiejską charakteryzują przeobrażenia użytkowania ziemi i cech społeczno-demograficznych, na skutek procesów urbanizacji. Z kolei K. Dziewoński (1987) patrzy na strefę podmiejską jak na część dużego systemu obejmującego zarówno miasto, jak i samą strefę. Oddziela ona obszary miejskie od wiejskich i może być w związku z tym traktowana jako strefa graniczna pomiędzy nimi. Podobne podejście reprezentuje S. Liszewski (1987), który lokuje strefę podmiejską w obrębie aglomeracji miejskiej, jako element złożonego systemu przestrzenno-funkcjonalnego. Według niego strefa podmiejska to zorganizowana część przestrzeni geograficznej, która przylega do terenów zainwestowanych miasta centralnego. Jest to obszar, na którym dochodzi do przenikania się form życia i działalności charakterystycznych dla miasta i wsi. W. Maik (1985) definiuje strefę podmiejską jako obszar przejściowy między wsią a miastem, głównie w płaszczyźnie przestrzennej, gdzie następuje mieszanie się form zagospodarowania przestrzeni i przejściowe typy osadnictwa, oraz w płaszczyźnie społecznej, czyli zróżnicowania i mobilności społeczności podmiejskiej, której cechą charakterystyczną jest kontaktowanie się $\mathrm{z}$ miastem.

Strefa podmiejska ma charakter przejściowy, o czym świadczą jej specyficzne cechy, wśród których M. Koter (1985) wymienia:

a) koncentrację ludności - większą niż na wsi, mniejszą niż w mieście,

b) zróżnicowanie struktury zawodowej z dużym udziałem działalności pozarolniczej,

c) systematyczne dojazdy ludności do miasta, 
d) urbanizację obszaru,

e) koegzystencję miejskich i wiejskich form osadniczych,

f) zmiany w strukturze wielkości i własności gruntów z tendencją wzrostu użytków pozarolniczych.

Różnorodność strefy podmiejskiej przejawia się w postaci funkcji, które są uwarunkowane rozwojem historycznym, wielkością, rangą gospodarczą i społeczną miasta oraz warunkami naturalnymi, w jakich się ono kształtuje. Do najczęściej wymienianych funkcji stref podmiejskich zaliczamy: rolniczą, wypoczynkową, mieszkaniową, komunalną, komunikacyjną, przemysłową, uzdrowiskową, sportową i naukową (Liszewski, 1987). Według J. Bańskiego (2008) najbardziej charakterystycznym procesem wyróżniającym strefę podmiejską jest dynamiczny rozwój budownictwa mieszkaniowego, przede wszystkim jednorodzinnego. Intensywność ruchu budowlanego jest funkcją wielkości ośrodka miejskiego i odległości od niego. Budownictwo mieszkaniowe koncentruje się w pobliżu głównych ciągów komunikacyjnych. Wzdłuż nich występują pasma wzmożonej aktywności gospodarczej, gdzie oprócz budownictwa rozwija się handel, usługi i działalność produkcyjna.

Pod wpływem urbanizacji postępująca komplikacja układów osadniczych powoduje zacieranie morfologicznych, społecznych i funkcjonalnych różnic pomiędzy miastem a wsią. Na obszarach dotąd wiejskich przekształceniom ulegają: wielkość działki, gęstość zabudowy, gęstość sieci dróg i ulic, wzrasta intensywność poziomu użytkowania ziemi, zmienia się kierunek użytkowania ziemi, wielkość terenów rekreacyjnych i zielonych oraz powierzchnia użytków zielonych (Staszewska, 2006). Według W. Drobka (2002) zakwalifikowanie jednostki osadniczej do grupy miast czy wsi wydaje się proste z punktu widzenia prawno-administracyjnego. Jednak występują jednostki osadnicze, które nie mają praw, a wyglądają i funkcjonują jak miasto.

\section{POŁOŻENIE JEDNOSTEK ADMINISTRACYJNYCH}

Gmina Bobrowniki oraz gmina Ożarowice znajdują się w centralnej części województwa śląskiego. Gmina Bobrowniki od 1999 roku leży w powiecie będzińskim, w jej skład wchodzi osiem sołectw. Sąsiaduje z dwoma obszarami miejskimi - Piekarami Śląskimi i Wojkowicami, oraz z czterema obszarami wiejskimi - gminami Świerklaniec, Ożarowice, Mierzęcice, Psary (ryc. 1). Przez gminę przebiega autostrada A1, droga krajowa nr 78 oraz droga wojewódzka nr 913.

Gmina Ożarowice położona jest w powiecie tarnogórskim, a w jej skład wchodzi siedem sołectw. Sąsiaduje z trzema obszarami miejskimi - Miasteczkiem Śląskim, Koziegłowami, Siewierzem, oraz z czterema obszarami wiejskimi - gminami Mierzęcice, Bobrowniki, Świerklaniec, Woźniki (ryc. 1). Przez gminę przebiega autostrada A1, droga ekspresowa S1, droga krajowa nr 78 oraz droga wojewódzka nr 913. Na omawianym obszarze zlokalizowany jest Międzynarodowy Port Lotniczy Katowice w Pyrzowicach. 
Ryc. 1. Fragment podziału administracyjnego woj. śląskiego w 2013 roku - gminy

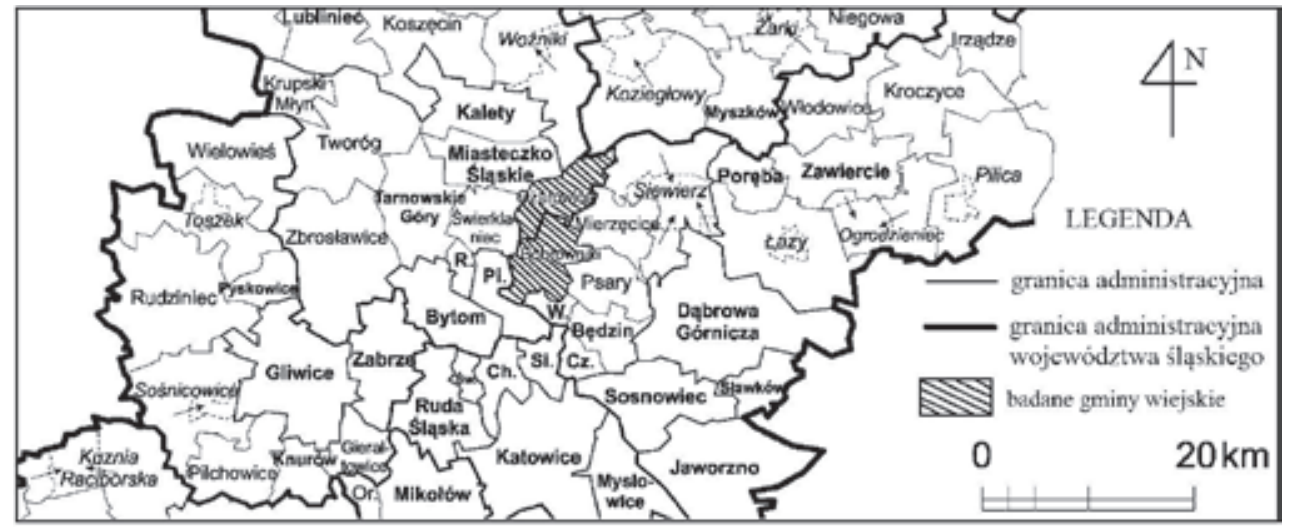

Źródło: S. Sitek, J. Runge i in. (2013)

\section{Ceny gruntów}

Do analizy wzięto przede wszystkim działki budowlane, jak również działki budowlano-usługowe bez zabudowy. Na całym omawianym obszarze zostały zinwentaryzowane 172 działki. W gminie Bobrowniki spisano 102 działki, natomiast w gminie Ożarowice - 70 działek (tab. 1). Taka rozpiętość w liczbie badanych działek z każdej gminy wynika z ograniczonego dostępu do ofert sprzedaży gruntów na terenie poszczególnych miejscowości. Informacje dotyczące sprzedaży działek, ich powierzchni oraz cen zostały zaczerpnięte ze stron internetowych, takich jak: dom.gratka.pl, www.krn.pl oraz otodom.pl, i obejmowały działki wystawione na sprzedaż w 2013 roku i w pierwszym kwartale 2014 roku.

Tab. 1. Ceny i powierzchnie działek pod zabudowę na terenie gmin Bobrowniki i Ożarowice

\begin{tabular}{|c|c|c|c|c|c|c|}
\hline \multirow{2}{*}{ Gmina } & \multirow{2}{*}{ Miejscowość } & \multirow{2}{*}{$\begin{array}{l}\text { Liczba } \\
\text { działek }\end{array}$} & \multicolumn{2}{|c|}{ Cena $[\mathrm{zl}]$} & \multicolumn{2}{|c|}{ Powierzchnia $\left[\mathrm{m}^{2}\right]$} \\
\hline & & & od & do & od & do \\
\hline \multirow{8}{*}{ Bobrowniki } & Bobrowniki & 15 & 35000 & 2538160 & 353,5 & 63454 \\
\hline & Dobieszowice & 5 & 70000 & 541970 & 1170 & 8338 \\
\hline & Myszkowice & 8 & 76000 & 990000 & 975 & 13481 \\
\hline & Sączów & 15 & 50000 & 1100000 & 800 & 20000 \\
\hline & Siemonia & 15 & 121220 & 269000 & 755 & 4895 \\
\hline & Rogoźnik & 15 & 35000 & 2320960 & 599 & 14506 \\
\hline & Twardowice & 14 & 78000 & 180000 & 1149 & 2431 \\
\hline & Wymysłów & 15 & 115000 & 360000 & 1027 & 4000 \\
\hline \multirow{7}{*}{ Ożarowice } & Celiny & 5 & 54000 & 247000 & 1010 & 2600 \\
\hline & Niezdara & 3 & 108000 & 170000 & 916 & 1680 \\
\hline & Ossy & 15 & 60000 & 387375 & 950 & 5261 \\
\hline & Ożarowice & 15 & 44000 & 322135 & 950 & 6835 \\
\hline & Pyrzowice & 9 & 75000 & 984802 & 800 & 20098 \\
\hline & Tąpkowice & 8 & 120000 & 448000 & 846 & 3500 \\
\hline & Zendek & 15 & 67340 & 380000 & 962 & 38820 \\
\hline
\end{tabular}

Źródło: opracowanie własne 
Grunty budowlane na terenie gminy Bobrowniki i Ożarowice cechuje różnorodność pod względem dostępności, cen oraz powierzchni działek. Najniższa, a zarazem najwyższa cena za działkę budowlaną wystąpiła w miejscowościach Bobrowniki oraz Rogoźnik, które położone są w południowej części gminy Bobrowniki. Działki budowlane o najmniejszej i największej powierzchni były dostępne w miejscowości Bobrowniki.

Na podstawie danych zgromadzonych w tabeli można zauważyć, że działki budowlane w gminie Bobrowniki cechują się większą różnorodnością niż w gminie Ożarowice. W gminie Ożarowice ceny działek budowlanych wahały się w przedziale od 44 tys. do 985 tys. zł, natomiast powierzchnia działek - od $800 \mathrm{~m}^{2}$ do $38820 \mathrm{~m}^{2}$. W gminie Bobrowniki ceny działek budowlanych mieściły się w przedziale od 35 tys. do $2,5 \mathrm{mln} \mathrm{z}$, natomiast powierzchnia działek wynosiła od $353,5 \mathrm{~m}^{2}$ do $63454 \mathrm{~m}^{2}$.

Różnorodność zgromadzonych danych wynika z położenia omawianych obszarów względem terenów miejskich, dostępności komunikacyjnej do pobliskich miast, dostępności do działalności usługowych, centrów handlowych, kulturalnych oraz z atrakcyjności okolicy. Im bliżej obszarów miejskich, tym tereny cieszą się większym popytem u zainteresowanych. Ludzie osiedlają się chętniej na obszarach podmiejskich, gdyż chcą uciec w miejsca czystsze, spokojniejsze, przyjazne, a zarazem znajdujące się w miarę blisko miasta, co znacznie ułatwia codzienne migracje polegające na dojazdach do pracy czy szkoły.

\section{Nowa ZABUDOWA}

Badaniom w terenie podlegała zabudowa mająca inny kształt niż prostokąt czy kwadrat. Zabudowa jednorodzinna o kształcie prostokąta czy kwadratu jest zabudową znacznie starszą, mającą ok. 40 lat. Podczas inwentaryzacji poza wiekiem zabudowy zostały wzięte pod uwagę: kryterium lokalizacji, typ zabudowy, pełnione funkcje oraz wielkość budynku. W kryterium lokalizacji została podana nazwa ulicy, przy której stoi budynek, został też sporządzony plan każdego sołectwa, na którym zaznaczono zinwentaryzowane budynki i osiedla mieszkaniowe. W typie zabudowy zostało określone, czy jest to budynek jednorodzinny, czy wielorodzinny. Opisano również osiedla pod względem typu zabudowy: czy są to osiedla jednorodzinne, wielorodzinne czy mieszane. Budynki zostały również przyporządkowane pod względem pełnionych funkcji: czy są to budynki mieszkaniowe, usługowe, czy mieszkaniowo-usługowe. Ostatnim elementem było wyznaczenie wielkości budynku. Do wielkości budynku zostały przyjęte określone kryteria: budynek został uznany za mały wtedy, gdy miał 1-1,5 kondygnacji, za średni, gdy miał 2-2,5 kondygnacji, za duży, gdy miał powyżej 2,5 kondygnacji.

$\mathrm{Na}$ omawianym obszarze można zaobserwować zjawisko wzrostu natężenia w ruchu budowlanym. W czasie przeprowadzania badań terenowych w 2013 roku za nową zabudowę zostało uznanych 621 budynków. Wszystkie powstałe budynki mają zabudowę jednorodzinną, a wszystkie powstałe osiedla są osiedlami jednorodzinnymi. Wśród pojedynczych budynków 25 uznano za duże, 171 za średnie, natomiast 130 za budynki małe. Na osiedlach mieszkaniowych dominowały budynki średnie i małe, z niewielkim udziałem budynków dużych. Spośród wszystkich budynków 617 pełni funkcję mieszkaniową, natomiast cztery pozostałe 
mieszkaniowo-usługową. Należy zaznaczyć, że na omawianym obszarze zapewniona jest podstawowa infrastruktura techniczna, tzn. przyłącza wody, gazu i kanalizacji. Najwięcej budynków z nowej zabudowy zostało wybudowanych na terenie gminy Bobrowniki - 418, spośród których 152 to pojedyncze budynki oraz dziewieć osiedli mieszkaniowych o łącznej liczbie 266 budynków (tab. 2).

Spośród wszystkich budynków najwięcej zostało zlokalizowanych w miejscowościach: Bobrowniki, Ożarowice, Rogoźnik oraz Wymysłów, natomiast najmniej - w miejscowościach Celiny, Niezdara i Pyrzowice. Nowe budynki powstały na wolnych działkach budowlanych pomiędzy starszą zabudową, jak również na większych wolnych przestrzeniach, gdzie większe skupiska nowych budynków utworzyły osiedla zabudowy jednorodzinnej o funkcjach mieszkaniowych.

Tab. 2. Nowe budownictwo na terenie gminy Bobrowniki

\begin{tabular}{|l|c|c|c|c|}
\hline \multicolumn{1}{|c|}{ Sołectwo } & $\begin{array}{c}\text { Pojedyncze } \\
\text { budynki }\end{array}$ & $\begin{array}{c}\text { Liczba osiedli } \\
\text { mieszkaniowych }\end{array}$ & $\begin{array}{c}\text { Lączna liczba } \\
\text { budynków } \\
\text { w osiedlach } \\
\text { mieszkaniowych }\end{array}$ & Razem \\
\hline Bobrowniki & 51 & 3 & 73 & 124 \\
\hline Dobieszowice & 14 & - & - & 14 \\
\hline Myszkowice & 5 & 2 & 37 & 106 \\
\hline Rogoźnik & 26 & 3 & 80 & 14 \\
\hline Sączów & 14 & - & - & 17 \\
\hline Siemonia & 17 & - & - & 18 \\
\hline Twardowice & 18 & - & - & 76 \\
\hline Wymysłów & 8 & 1 & 68 & \\
\hline
\end{tabular}

Źródło: opracowanie własne

Na terenie gminy Ożarowice powstały 203 nowe budynki, z których 174 to pojedyncze budynki, oraz jedno osiedle mieszkaniowe o łącznej liczbie 29 budynków (tab. 3).

Tab. 3. Nowe budownictwo na terenie gminy Ożarowice

\begin{tabular}{|l|c|c|c|c|}
\hline Sołectwo & $\begin{array}{c}\text { Pojedyncze bu- } \\
\text { dynki }\end{array}$ & $\begin{array}{c}\text { Liczba osiedli } \\
\text { mieszkaniowych }\end{array}$ & $\begin{array}{c}\text { Lączna liczba } \\
\text { budynków } \\
\text { w osiedlach } \\
\text { mieszkaniowych }\end{array}$ & Razem \\
\hline Celiny & 3 & - & - & 3 \\
\hline Niezdara & 10 & - & - & 10 \\
\hline Ossy & 8 & 1 & 29 & 37 \\
\hline Ożarowice & 86 & - & - & 86 \\
\hline Pyrzowice & 9 & - & - & 30 \\
\hline Tąpkowice & 30 & - & - & 28 \\
\hline Zendek & 28 & - & - & \\
\hline
\end{tabular}

Źródło: opracowanie własne 
Natężenie ruchu budowlanego na terenie gminy Bobrowniki i gminy Ożarowice jest zróżnicowane. Najintensywniej to zjawisko zachodzi w pierwszej z wymienionych gmin. Różnice w ruchu budowlanym pomiędzy gminami mogą wynikać z różnych przyczyn. Po pierwsze, może być to uzależnione od otaczających jednostek administracyjnych. Gmina Bobrowniki sąsiaduje z dwoma obszarami miejskimi należącymi do większego zespołu miejskiego, jakim jest aglomeracja górnośląska, której oddziaływanie jest znacznie silniejsze niż pojedynczych obszarów miejskich, sąsiadujących z gminą Ożarowice.

Drugą przyczyną jest dostępność komunikacyjna. Komunikacja drogowa lepiej rozwinięta jest na obszarze gminy Ożarowice, co jest związane z lokalizacją na terenie gminy Międzynarodowego Portu Lotniczego Katowice w Pyrzowicach. Znajdują się tu też węzeł drogowy autostrady A1 i drogi ekspresowej S1 oraz przebiega droga krajowa nr 78 i droga wojewódzka nr 913. Natomiast jeżeli weźmiemy pod uwagę komunikację zbiorową, to lepsze połączenia z pobliskimi jednostkami administracyjnymi funkcjonują na terenie gminy Bobrowniki. Wiadomo, że coraz więcej ludzi jest mobilnych i posiada własny samochód, jednak komunikacja zbiorowa także odgrywa ważną rolę. Przede wszystkim jest tańsza oraz nie wymaga od podróżnych posiadania odpowiednich uprawnień.

Trzecia przyczyna to wypoczynek i rekreacja. Na terenie gminy Bobrowniki położony jest park w Rogoźniku wraz z dwoma zbiornikami wodnymi, na terenie sołectwa Wymysłów - kompleks leśny oraz w niewielkiej odległości park w Świerklańcu oraz zbiornik wodny Kozłowa Góra. W gminie Ożarowice również występują kompleksy leśne, jednak w niewielkim stopniu pełnią one funkcje rekreacyjną i wypoczynkową.

Czwartą przyczyną różnic w ruchu budowlanym jest dostępność działek budowlanych. Na obszarze gminy Ożarowice większość działek w otoczeniu portu lotniczego przeznaczona jest pod działalność stanowiącą zaplecze usługowe lotniska. Dodatkowo występują pewne ograniczenia w budownictwie z powodu samego funkcjonowania lotniska. W pozostałej części gminy powstają nowe budynki. Na obszarze gminy Bobrowniki nie występują takie ograniczenia. Coraz więcej wolnych terenów przeznaczanych jest pod nowe budownictwo.

Na całym omawianym obszarze, któremu poświęcony jest niniejszy artykuł, następuje wzrost aktywności w ruchu budowlanym. Można wysnuć wniosek, że jest to obszar atrakcyjny, o dużych walorach przyrodniczych. Tutejsi mieszkańcy mogą korzystać z funkcji rekreacyjnych i wypoczynkowych, jakie oferują im kompleksy leśne, parkowe oraz zbiorniki wodne. Można zakładać, że w przyszłości coraz więcej terenów zostanie przeznaczonych pod zabudowę mieszkaniową, gdyż zainteresowanie nabywców nie słabnie.

\section{ZAKOŃCZENIE}

Na omawianym obszarze następuje wzrost popytu na działki budowlane, a tym samym następuje rozwój nowego budownictwa. Powstają budynki przeważnie o funkcji mieszkaniowej, jak również o funkcji mieszkaniowo-usługowej, jednak te ostatnie w znacznie mniejszej liczbie. Budynki lokalizowane są przeważnie na nieużytkach oraz w wolnych przestrzeniach pomiędzy starszą, już istniejąca zabudową.

Z przeprowadzonej analizy wynika, że obszary wiejskie zlokalizowane w strefie oddziaływania zespołu miejskiego stanowią ważne zaplecze społeczne. Coraz więcej osób wybiera 
je na miejsce zamieszkania, dzięki czemu ma miejsce korzystny rozwój obszarów wiejskich, które stanowią strefę podmiejską większego ośrodka miejskiego.

Na obszarach o bardzo intensywnym ruchu budowlanym ma miejsce podział dotychczasowych gruntów rolnych na działki budowlane, przez co zabudowa mieszkaniowa rozwija sie w głąb pól uprawnych (prostopadle do głównej drogi). Skutkuje to powstaniem wąskich i wydłużonych pasm zabudowy, mających szerokość kilkunastu metrów, a wybiegających nawet kilkaset metrów w głąb pól i mających utrudniony dostęp do drogi głównej.

Konsekwencją dynamicznego rozwoju budownictwa w otoczeniu obszarów miejskich jest wzrost popytu na ziemię. Wysokie ceny gruntów w mieście zmuszają inwestorów do poszukiwania gruntów pod nowe inwestycje na terenach podmiejskich. Największym zainteresowaniem cieszą się grunty położone w niewielkiej odległości od głównych ciągów komunikacyjnych. Wysoki popyt doprowadza do tego, że ceny rosną w bardzo szybkim tempie i stają się porównywalne z cenami gruntów w miastach (Bański, 2008).

\section{Literatura}

\section{References}

Bański, J. (2008). Strefa podmiejska - już nie miasto, jeszcze nie wieś. W: A. Jezierska-Thole, L. Kozłowski (red.). Gospodarka przestrzenna w strefie kontinuum miejsko-wiejskiego w Polsce. Toruń: Uniwersytet Mikołaja Kopernika, 29-43.

Drobek, W. (2002). Polskie nowe miasta 1977-2001. W: J. Słodczyk (red.). Przemiany bazy ekonomicznej i struktury przestrzennej miast. Opole: Uniwersytet Opolski, 71-84.

Dziewoński, K. (1987). Strefa podmiejska - próba ujęcia teoretycznego. Przegląd Geograficzny, 59(1-2), 55-63.

Jurek, J. (1991). Zmiany struktury społeczno-ekonomicznej wsi w strefie podmiejskiej Poznania. Poznań: Wydawnictwo Naukowe Uniwersytetu Adama Mickiewicza w Poznaniu, 36-39.

Koter, M. (1985). Kształtowanie się strefy podmiejskiej w świetle badań historyczno-geograficznych. Acta Universitstis Lodziensis, Folia Geographica, 5, 61-73.

Liszewski, S. (1987). Strefa podmiejska jako przedmiot badań geograficznych. Próba syntezy. Przegląd Geograficzny, 59(1-2), 65-79.

Maik, W. (1985). Charakterystyka strefy podmiejskiej w kategoriach funkcjonalnych próba rekonstrukcji modelu pojęciowego i metody badawczej. Acta Universitstis Lodziensis, Folia Geographica, $5,41-60$.

Pryor, R. (1968). Defining the Rural - Urban Fringe, Social Forces. Chapel Hill: University of North Carolina Press, 47(2), 202-215.

Sitek S., Runge, J. i inni (2013). Społeczno-gospodarcze i przestrzenne kierunki zmian regionalnego oraz lokalnych rynków pracy województw śląskiego - SGP WSL. Raport końcowy. Sosnowiec: Wydawnictwo Uniwersytetu Śląskiego.

Staszewska, S. (2006). Miasto czy wieś - uwarunkowania rozwoju i zagospodarowanie podmiejskich jednostek osadniczych. W: K. Heffner, T. Marszał Małe miasta - studium przypadków. Łódź: Uniwersytet Łódzki, 61-73.

Marlena Dyszy, mgr, Uniwersytet Śląski w Katowicach, Wydział Nauk o Ziemi w Sosnowcu, Katedra Geografii Ekonomicznej. Absolwentka studiów magisterskich na Wydziale Nauk o Ziemi Uniwersytetu Śląskiego w Katowicach (kierunek: geografia, specjalność: zagospodarowanie przestrzenne), od 2014 roku studentka studiów doktoranckich na tym samym wydziale w Katedrze Geografii Ekonomicznej. Obszar zainteresowań naukowych związany jest z geografią społeczno-ekonomiczną, w szczególności geografią osadnictwa. Zainteresowania wynikają z racji zamieszkania w obszarze podmiejskim, jak również z problematyki obszarów o cechach miejsko-wiejskich. 
Marlena Dyszy, graduate at the Faculty of Earth Sciences, University of Silesia in Katowice (Major: Geography, specializing in land use planning), since 2014. PhD student at the same Faculty in the Department of Economic Geography. Her research interests include the socio-economic geography, in particular settlement. Interest result from living in a suburban area, as well as areas with special problems of urban-rural.

\section{Adres/address:}

Uniwersytet Śląski w Katowicach Wydział Nauk o Ziemi w Sosnowcu

Katedra Geografii Ekonomicznej

ul. Będzińska 60, 41-200 Sosnowiec, Polska

e-mail: marlena.dyszy@gmail.com 